\title{
STRATEGI INOVASI TENUN SILUNGKANG SEBAGAI WARISAN DUNIA TAK BENDA/ ICON PRIMADONA WISATA
}

\author{
Rose Rahmidani, S.Pd, MM, Dessi Susanti, S.Pd, M.Pd \\ Fakultas Ekonomi, Universitas Negeri Padang \\ rose_unp@yahoo.com \\ Fakultas Ekonomi, Universitas Negeri Padang \\ Mazaya_unp@yahoo.co.id
}

\begin{abstract}
West Sumatra is one of the central areas of potential creative industries. Creative industries are seeded West Sumatra is woven. Weaving is a mainstay in West Sumatra is woven Silungkang. Stretching weaving Silungkang on national and international markets admirable. Seen that until now it turns weaving products Silungkang West Sumatra is still very popular and received support from the government so that it can compete and able to compete in national and international markets. Surely this can be a learning experience as well as an input for creative entrepreneurs similar products in terms of product innovation strategy to be one of the keys to success in the competitive free market that we enter. This study aims to produce a road map Silungkang weaving innovation strategy and generate profiles factors Silungkang weaving innovation that still exist in the arena of national and international weaving
\end{abstract}

Keywords:Strategi Inovasi, Faktor Faktor Inovasi, Tenun Silungkang

\section{PENDAhuluan}

Mengingat saat ini dunia industri telah berada pada era ekonomi gelombang keempat untuk itu sangat diperlukan perumusan strategi inovasi yang kreatif agar industri kreatif dapat berkembang dan Sumatera Barat dapat menciptakan daerah sentra industri kreatif potensial yang dapat bergeliat dalam era ekonomi kreatif gelombang keempat pada masa sekarang ini.

Terlihat bahwa sampai sekarang ternyata produk tenun Silungkang Sumatera Barat masih sangat diminati dan mendapat dukungan dari pemerintah sehingga dapat bersaing dan mampu berkompetisi dalam pasar nasional maupun internasional. Tentunya hal ini dapat menjadi pembelajaran serta masukan bagi pengusaha produk-produk kreatif sejenis dalam hal strategi inovasi produk yang menjadi salah satu kunci keberhasilan dalam persaingan pasar bebas yang akan kita masuki.

Berdasarkan latar belakang di atas penelitian ini sangat penting untuk dilakukan. Penelitian ini akan memberikan inspirasi dan gagasan bagi pengusaha kreatif tenun yang ada di Sumatera Barat khususnya dan Indonesia pada umumnya, terkait dengan langkah jitu dan strategi inovasi yang turun temurun di lakukan oleh tenun Silungkang. Penelitian ini akan menghasilkan road map strategi inovasi serta profil faktor inovasi tenun Silungkang sehingga tetap eksis di kancah pertenunan nasional dan internasional. Permasalahan dalam penelitian ini adalah bagaimanakah strategi inovasi usaha kreatif tenun Silungkang dari masa ke masa dan apa faktor-faktor inovasi tenun Silungkang sehingga tetap eksis di kancah pertenunan nasional dan internasional.

\section{KAJIAN LITERATUR DAN PEGEMBANGAN HIPOTESIS}

Ada beberapa cara yang dapat ditempuh untuk menghasilkan produk yang inovatif yaitu dengan : 1) Mengembakan atribut produk baru terdiri dari adaptasi (gagasan lain atau pengembangan produk), modifikasi (mengubah warna, gerakan, suara, bau, bentuk dan rupa), memperbesar (lebih kuat, lebih panjang, lebih besar), memperkecil (lebih ramping, lebih ringan, lebig kecil), substitusi (bahan lain, proses, sumber tenaga), 
penataan kembali (pola lain, tata letak lain, kompenen), membalik (luar menjadi dalam), kombinasi (mencampur, meramu, asortasi, rakitan, unit gabungan, kegunaan, daya pikat, dan gagasan), 2) Mengembangkan beragam tingkat mutu, 3) Mengembangkan model dan ukuran produk (profilerasi produk) [1].

Ada tiga jenis inovasi: inovasi produk, proses inovasi, dan inovasi pasar yaitu : 1) Inovasi produk memiliki makna paling jelas yaitu menghasilkan pendapatan, 2) Inovasi proses menyediakan sarana untuk menjaga dan meningkatkan kualitas dan untuk menghemat biaya, 3) Inovasi pasar memperhatikan peningkatan target pasar campuran (mixed og target market) dan bagaimana pasar yang dipilih adalah yang terbaik dilayani [2].

Terdapat delapan faktor yang mempengaruhi keberhasilan sesuatu inovasi. yaitu : 1) Mengadakan hubungan baik dengan organisasi luar melalui komunikasi dan bersedia untuk menerima dan mengadaptasi idea-idea dari luar, 2) Menganggap inovasi sebagai satu usaha jangka panjang yang menuntut keterlibatan semua pihak, 3) Mengikut prosedur-prosedur yang telah ditetapkan, komitmen semua pihak terutama pihak atasan organisasi, 4) Pekerjaan yang berkualitas seperti mengontrol mutu, 5) Berorientasi kekuatan pasar mengikut kehendak dan keperluan konsumen, 6) Memberikan layanan yang terbaik bagi pengguna, 7) Possessing the presence certain key individuals sebagai contoh product champions dan sebagainya.

\section{METODE PENELITIAN}

Penelitian ini menggunakan desain penelitian deskriptif dan kualitatif. Penelitian kualitatif merupakan penelitian yang menelaah fenomena-fenomena sosial budaya dan interaksi manusia yang berlangsung secara wajar, alamiah, alamiah,dan bukan dalam kondisi yang terkendali atau bersifat laboratoris [3].

Tahapan-tahapan dalam penelitian ini adalah: 1) Studi awal telah mencoba menelusuri kisah perjalanan tenun Silungkang hingga rencananya untuk menggelar festival songket internasional, 2) Mengindentifikasi strategi inovasi tenun Silungkang, 3) Mengidentifikasi faktor-faktor inovasi tenun Silungkang sehingga tetap eksis di kancah pertenunan nasional dan internasional, kemudian dengan melakukan indeep interview menekankan kepada membedakan tiga jenis inovasi: inovasi produk, proses inovasi, dan inovasi pasar [2], 4) Berdasarkan hasil yang diperoleh dari tahapan penelitian sebelumnya, dapat diberikan rekomendasi bentuk kebijakan dan tindakan yang seharusnya dilakukan oleh seluruh pihak pemangku kepentingan untuk melakukan dukungan nyata agar usaha kreatif tenun nasional bersaing dalam inovasi produk dan mampu berkompetisi di ajang Masyarakat Ekonomi Asean.

Penelitian ini berlokasi di Silungkang Kota Sawah Lunto Sumatera Barat. Kabupaten dan kota sebagai sampel penelitian diambil dengan teknik purposive sampling yaitu daerah yang memiliki usaha kreatif tenun dan dalam hal ini Silungkang menjadi pilihan karena Silungkang menjadi daerah pengembangan tenun di Sumatera Barat.

Pengumpulan data dilakukan dengan observasi, wawancara mendalam (terstruktur dan tidak terstruktur). Penelitian ini menggunakan data sekunder dan data primer.

Data sekunder dikumpulkan dengan menggunakan metode observasi dan studi dokumentasi terhadap dokumen yang ada di Dinas Perindustrian dan Perdagangan, BPS dan instansi lain yang terkait. Sedangkan data primer dikumpulkan melalui wawancara dengan responden penelitian (pengusaha tenun Silungkang), tokoh adat Minangkabau yang dikenal dengan tungku tigo sajarangan yaitu alim ulama, niniak mamak dan cadiak pandai dan expert dari dinas perindustrian dan perdagangan. Penentuan responden penelitian untuk alim ulama, niniak mamak, cadiak pandai dan expert dinas perindustrian dan perdagangan dilakukan dengan teknik snowball sampling [4].

Teknik analisis data dilakukan dengan menggunakan analisis kualitatif model yang mengemukakan bahwa analisis data dalam penelitian kualitatif dilakukan terus menerus dan interaktif sampai tuntas sehingga datanya jenuh. Aktivitas dalam analisis data yaitu data reduction, data display dan conclusion drawing/verification [5]. 


\section{HASIL DAN PEMBAHASAN}

Hingga saat ini pertenunan di Silungkang masih diturunkan secara turun temurun. Perkembangan songket tradisional silungkang mengalami pasang surut. Salah satunya yakni masuknya Alat Tenun Bukan Mesin (ATBM) dan Alat Tenun Mesin (ATM). Sehingga mempengaruhi para penenun songket tradisional silungkang. dahulu alat tenun songket tradisional silungkang yakni alat tenun gedogan sekitar tahun 1945, dimana penenun duduk dilantai dan pinggang diikat.

Sesuai dengan pekembangan zaman, masyarakat silungkang pun mulai menghidupkan kembali tenun songket tradisional silungkang dengan cara memodifikasi alat tenun tradisional diangkat ke ATBM yang hingga saat ini sudah mulai dipakai oleh para penenun silungkang. Alat Tenun Bukan Mesin ini sudah mulai dipakai sekitar tahun 1975.

ATBM diperkenalkan oleh pemerintahan kolonial pada awal tahun 1930-an. Terdapat beberapa modifikasi, diantaranya pada bangku tempat duduk penenun, dan karok atau gun dinaikkan dan diturunkan dengan pijakan kaki pada pedal yang dikaitkan pada karok itu. Sekitar 5 tahun kemudian, jumlah ATBM meningkat empat kali lipat. Produksi tumbuh dengan pesat dan laki-laki juga ikut menenun untuk memenuhi permintaan pasar (Achjadi dkk, 2013:9).

Dari uraian di atas, dapat disimpulkan bahwa masyarakat silungkang telah memakai ATBM yang telah dimodifikasi sebagai alat tenun untuk menenun kain tenun songket silungkang. produksi kain tenun songket silungkang yang tumbuh dengan cepat dan terlihat dari permintaan pasar yang meningkat sehingga penenun silungkang tidak hanya dari kaum perempuan tetapi juga kaum laki-laki.

Masyarakat silungkang saat ini masih memakai ATBM untuk membuat songket tradisional silungkang, dimana ATBM sendiri merupakan modifikasi dari alat tenun tadisional yang disesuaikan dengan penenun silungkang sendiri.
Untuk menghasilkan kain songket yang bervariasi dan inovasi, pada perkembangan selanjutnya para pengrajin kain songket silungkang memadukan teknik tenun ikat dengan teknik songket. Selain benang katun, bahan yang digunakan juga diambil dari benang sutera dengan hiasan benang makau atau benang katun berwarna.

Pada masa lalu pewarnaan benang lusi dilakukan secara tradisional. Caranya, sebelum diberi warna, benang harus dibersihkan dari kotoran-kotoran dan unsurunsur lain yang akan menghalangi masuknya zat pewarna. Kemudian, benang diberi zat pemutih (soda abu). Zat itu dapat diperoleh dengan mudah di toko-toko kimia atau apotek. Setelah itu, benang itu dibagi menjadi beberapa bagian yang kemudian dicelup dengan warna yang diperlukan. Ini membuktikan bahwa pengrajin tenun Silungkang telah mengenal cara-cara modern dalam proses pemutihan bahan barang tenun.

Seiring dengan perkembangan zaman dan selera pasar ternyata dalam pewarnaan, tenun silungkang kembali mengikuti pola lama artinya pada penggunaan warna-warna kembali ke natural atau warna alam sebagai bahan pewarna, diharapkan menjadi salah satu inovasi untuk menarik konsumen, mengingat kembali boomingnya istilah kembali pada alam (back to nature) hal ini juga sekaligus menjadi salah satu sumber keunggulan kompetitif dari produk kain asal silungkang.

$\begin{array}{lrr}\text { Tenunan } & \text { Silungkang } & \text { mempunyai } \\ \text { kelebihan } & \text { pada } & \text { motif. } \\ \text { Keistimewaan lain terdapat } & \text { pada }\end{array}$
ragamnya. Ada songket ikat, songket batabua, penuh, benang dua, dan songket selendang lebar. Keunikan itulah yang membuat songket Silungkang diminati pembeli dari Malaysia dan Singapura.

Motif tenun muncul dari daya kreasi dan imaginasi pengrajin tenun, hal ini berarti bahwa tenun silungkang erat kaitannya dengan artistik dan nilai seni yang muncul 
dari orang orang yang punya bakat seni yang tinggi.

Pengrajin tenun Songket Silungkang tidak hanya memproduksi satu jenis songket tertentu, seperti sarung dan atau kain saja. Akan tetapi, sudah merambah ke produk jenis lain, seperti: gambar dinding, taplak meja, permadani bergambar, baju wanita, sprey, baju kursi, bantal permadani, selendang, serber, kain lap dapur, sapu tangan, bahan kemeja ("hem"), tussor (bahan tenun diagonal), dan taplak meja polos.

Produk-produk kerajinan tangan tersebut merupakan program inovatif dan Kreatif melalui Kolaborasi Nusantara.

beberapa jenis songket yang ada, sebagian diantaranya sudah melakukan inovasi-inovasi baru sebagai salah satu strategi dalam meraih persentase pasar, semuanya masih mampu mempertahankan keaslian motif yang dihasilkan walaupun sudah disesuaikan dengan perkembangan zaman.

Nilai keindahan tercermin dari motif ragam hiasnya yang dibuat sedemikian rupa, sehingga memancarkan keindahan. Sedangkan, nilai ketekunan, ketelitian, dan kesabaran tercermin dari proses pembuatannya yang memerlukan ketekunan, ketelitian, dan kesabaran. Tanpa nilai-nilai tersebut tidak mungkin akan terwujud sebuah tenun songket yang bagus.

Perkembangan Sosial media juga ternyata berimbas kepada cara penjualan yang digunakan oleh para pengrajin dalam memasarkan kain tradisional mereka dengan mulai memiliki account di Facebook/blog sebagai salah satu metode pemasaran baru bagi mereka. Dimana kefektifan dari metode sosial media masih perlu pendalaman lebih untuk melihat dampaknya terhadap penjualan kain asal silungkang.

Faktor inovasi tenun silungkang diantaranya adalah mengadakan hubungan baik dengan organisasi luar melalui komunikasi dan bersedia untuk menerima dan mengadaptasi idea-idea dari luar. Faktor inovasi yang berikutnya adalah pekerjaan yang berkualitas seperti mengontrol mutu.

Karena keunikan serta keragaman motif dan nilai sejarah yang melekat pada kerajinan yang merupakan kearifan lokal masyarakat kota Sawah Lunto, sejak berabad-abad silam, sehingga kerajinan songket silungkang bisa menggeliatkan ekonomi masyarakat dan mampu menembus pasar-pasar internasional.

\section{KESIMPULAN}

Kesimpulanberisirangkumansingkatatash asilpenelitiandanpembahasan.[Times New Roman, 11, normal].

Berdasarkan pemaparan yang telah diungkapkan pada bab-bab sebelumnya, maka dapat disimpulkan: 1) Dapat dikatakan bahwa kain tenun Sumatera Barat atau Songket Silungkang, adalah seni tenun yang sangat tinggi nilainya; sangat berhubungan erat dengan Kebudayaan dan kebiasaan masyarakat setempat dalam kegiatan adatnya seringkali berpakaian menggunakan kain tenun songket; baik untuk kain kebaya, ikat kepala, sarung, baju teluk belanga dll. 2) Strategi inovasi tenun silungkang adalah: a) Inovasi produk yang terdiri dari : (1) Peralatan dan bahan Dahulunya menggunakan gedogan kemudian meningkat dengan munculnya Alat Tenun Bukan Mesin dan meningkat lagi dengan munculnya Alat Tenun Mesin. Kalau dahulunya menggunakan katun $100 \%$ maka sekarang sudah menggunakan benang yang bervariasi sesuai permintaan pasar seperti sutera, (2) Motif Ragam Hias Tenun Songket Silungkang Tenunan Silungkang mempunyai kelebihan pada motif. Keistimewaan lain terdapat pada ragamnya, artinya motif dan ragam tenun (difersifikasi) berkembang dari waktu ke waktu seiring dengan perkembangan zaman dan mengikuti kebutuhan pasar, (3) Nilai Budaya. Nilai nilai kesakrakalan dan nilai nilai yang menjadi acuan dalam kehidupan sehari hari masyarakat yang ada pada tenun silungkang memberikan kekuatan tersendiri 
sehingga mampu memancarkan keindahan tenun dan ini menjadi keistimewaan dari tenun silungkang. b) Inovasi Proses, teknik pembuatan tenun songket, Seiring dengan perkembangan zaman dan selera pasar ternyata dalam pewarnaan, tenun silungkang kembali mengikuti pola lama artinya pada penggunaan warna-warna kembali ke natural atau warna alam sebagai bahan pewarna, mengingat kembali boomingnya istilah kembali pada alam (back to nature). Penggunaan warna warna alam tersebut dengan melalui proses pencelupan, c) Inovasi pemasaran, Perkembangan Sosial media juga ternyata berimbas kepada cara penjualan yang digunakan oleh para pengusaha tenun silungkang dalam memasarkan kain tradisional mereka dengan mulai memiliki account di Facebook/blog. 3) Faktor Inovasi Tenun Silungkang, a) Mengadakan hubungan baik dengan organisasi luar, dalam hal ini adalah instansi pemerintah dan swasta melalui kerja sama berupa wisata belanja produk tenun silungkang bagi tamu yang datang lewat event event tertentu, b) Pekerjaan yang berkualitas seperti mengontrol mutu, sehingga menghasilkan tenun yang bagus dan berkualitas.

\section{REFERENSI}

[1] Kotler, Philip and Keller, K. L. (2009). Marketing Management. Edisi 13. Prentice Hall, Inc., New Jersey.

[2] Jukka, Ojasalo (2008) "Management of innovation networks: a case study of different approaches", European Journal of Innovation Management, Vol. 11 Iss: 1, pp.51- 86

[3] Faisal, Sanapiah. 1990, Penelitian Kualitatif: Dasar-dasar dan Aplikasi, Yayasan Asih Asah Asuh Malang (YA3 Malang), edisi 1, cet. I
[4] Iskandar. 2009. Metodologi Penelitian Pendidikan dan Sosial. Jakarta: Gaung Persada Press.

[5] Miles, Matthew B dan A Michael Huberman. (2007). Analisis Data Kualitatif. Buku Sumber tentang metode-metode baru. Jakarta: Universitas Indonesia Press. 
